\title{
Consistent lithospheric modification as carbonated melt evolves: insights from wehrlite and melt pockets in peridotite from the eastern China
}

\author{
LiXU DENG $^{1,2}$, YONGSHENG LiU ${ }^{2}$, XiAnlei GENG ${ }^{2,3}$
}

${ }^{1}$ College of Civil Engineering and Architecture,China Three Gorges University, Yichang 443002, China

${ }^{2}$ State Key Laboratory of Geological Processes and Mineral Resources, School of Earth Sciences, China University of Geosciences, Wuhan 430074, China

${ }^{3}$ East China University of Technology, Nanchang 330013, China

The recycled carbonates are one of important way of carbonated melts in the mantle, and then carbonated melt can converted to alkali basaltic melt through reactions with lithospheric mantle. However, such evolution has rarely shown to exist in nature and requires highly speculative. To adders this issue, here we investigate the petrography, in-situ mineral chemistry of Changle wehrlite and melt pockets in mantle xenoliths from Shandong province, China, combined with in-situ $\mathrm{Sr}$ isotopic composition of clinopyroxene (cpx) in the wehrlite. Petrographic features (e.g., carbonate melt inclusions and apatite) and geochemical characteristics of cpx (e.g., enrichment of large ion lithophile elements and light rare earth elements (LREE) and high $(\mathrm{La} / \mathrm{Yb})_{\mathrm{N}}, \mathrm{Eu} / \mathrm{Ti}$ ratios) indicate that the Changle wehrlite was formed by carbonatite metasomatism. Cpx in the wehrlite with relatively high ${ }^{87} \mathrm{Sr} /{ }^{86} \mathrm{Sr}$ ratio $(>0.7033)$, combining with new $\mathrm{Mg}$ and $\mathrm{He}$ isotopic data of the Changle wehrlites, indicate that the carbonated melt recorded by Changle wehrlite could be contaminated with variable proportions of recycled oceanic crustal material.

Glasses in the Changle melt pocket show high $\mathrm{SiO}_{2}$ and low $\mathrm{CaO}$ contents and enriched in LREE, $\mathrm{Nb}$ and $\mathrm{Ta}$ compositions, suggesting that the melt pocket likely originated from the breakdown of orthopyroxenes with variably minor of external melts. The reacted melts were alkaline silicate melts because of absence of carbonate and low $\mathrm{CaO}$ but high $\mathrm{Na}_{2} \mathrm{O}+\mathrm{K}_{2} \mathrm{O}$ contents of the melt pockets. Such alkaline silicate melts could be converted from carbonated melts which recording by the Changle wehrlite, during which precipitation of apatite accounts for genesis of positive $\mathrm{Nb}-\mathrm{Ta}$ anomalies. Therefore, such carbonatite metasomatsim caused by deep subduction of western Pacific slab could have played an important role not only in modifying the minerals and chemical composition of the mantle beneath the eastern block of the NCC, but also in origin of alkali basalts. 